\title{
Incidence of Chronic Hepatitis B and C Virus Infection in Damietta, Egypt
}

\author{
Hussein M. El-Shafei*
}

Ministry of Agriculture, Port Said, Egypt

\begin{abstract}
We investigated the incidence of Hepatitis $B(\mathrm{HBV})$ and Hepatitis C $(\mathrm{HCV})$ virus infection among patients with liver disease in Damietta Egypt from 2003 to 2005. Of the 146 liver patients studied, 25.3\% had HCV and 8.9\% had HBV. The incidence of HBV and HCV infection was greater in males than females, especially for HCV. There was a sharp increase in the number of cases of HCV in liver patients in 2005 compared with 2003 (2.2-fold higher in men and 2.3-fold higher in women). Over the years, the rate of HBV and HCV infection was higher in male than female patients $(69.2 \%$ versus $30.7 \%$ for HBV and $67.5 \%$ versus $32.4 \%$ for HCV Alanine Amino-Transferase (ALT) $\boldsymbol{\alpha}$-glutathione-s- transferase were used a biomarker of Hepatocellular damage. IgG anti-HCV is related to the elevation of ALT levels and can be used as a serologic marker to indicate the presence of active HCV induced liver damage.
\end{abstract}

Keywords: Hepatitis B; Hepatitis C; Hepato cellular; Carcinoma; Liver patients

\section{Introduction}

Hepatitis is an infection of the liver caused by several viruses, the most common of which are Hepatitis A, B and C. Both Hepatitis B Virus (HBV) and Hepatitis C Virus (HCV) are spread mainly through contaminated blood and blood products, sexual contact and contaminated needles. Although there has been a decrease in the incidence of viral hepatitis over the last decade, it is still the most common cause of chronic liver disease worldwide [1-5]. Globally, the number of individuals infected with HBV has been estimated to be 350 million, $40 \%$ of whom may progress to cirrhosis, liver failure and hepatocellular carcinoma [3]. Approximately 170 million people worldwide are affected with HCV. It is the most common chronic infection in the United States of America (USA) and is responsible for $40 \%$ of chronic liver disease [4]. HCV infections are the principal cause of chronic liver disease, cirrhosis, carcinoma and liver transplantation. Over 17,000 people with chronic liver disease were listed for liver transplantation in 2003, with $>10 \%$ expected to die before the operation [6]. Although viral hepatitis is a global health problem, there is a considerable variability in $\mathrm{HBV}$ and $\mathrm{HCV}$ rates between and within countries and between ethnic groups [2]. For instance, the prevalence of $\mathrm{HCV}$ in people with chronic liver disease has been estimated, 74\% in Egypt [7]. Egypt has the highest countrywide prevalence of Hepatitis C Virus (HCV) in the world, with an estimated 8-10 million among a population of 68 million having been exposed to the virus and 5-7 million active infections. The infection with HBV or HCV among the positive patients has been persisting for some time before the appearance of the clinical symptom. These data will show the social importance of HBV and HCV infections in the region In Egypt, schistosomiasis was traditionally the most important public health problem and infection with Schistosoma mansoni the major cause of liver disease. From the 1950s until the 1980s, the Egyptian Ministry of Health $(\mathrm{MOH})$ undertook large control campaigns using intravenous tartar emetic, the standard treatment for schistosomiasis, as community-wide therapy. This commendable effort to control a major health problem unfortunately established a very large reservoir of Hepatitis C Virus (HCV) in the country. By the mid-1980s, the effective oral drug, praziquantel, replaced tartar emetic as treatment for schistosomiasis in the entire country. This both reduced schistosomal transmission and disease and interrupted the "occult" HCV epidemic. It was evident when diagnostic serology became available in the 1990s that $\mathrm{HCV}$ had replaced schistosomiasis as the predominant cause of chronic liver disease. Epidemiological studies reported a high prevalence and incidence of HCV, particularly within families in rural areas endemic for schistosomiasis. Clinical studies showed 70\% to $90 \%$ of patients with chronic hepatitis, cirrhosis, or hepatocellular carcinoma had HCV infections. Co-infections with schistosomiasis caused more severe liver disease than infection with HCV alone. Schistosomiasis was reported to cause an imbalance in HCV-specific T-cell responses leading to increased viral load, a higher probability of HCV chronicity, and more rapid progression of complications in co-infected persons. As complications of HCV usually occur after 20 years of infection, the peak impact of the Egyptian outbreak has not yet occurred. Efforts have been initiated by the Egyptian $\mathrm{MOH}$ to prevent new infections and complications of $\mathrm{HCV}$ in the estimated 6 million infected persons [8]. The Nile River has been an epicenter for schistosomiasis since antiquity. In 1980, an estimated $10 \%$ of the 200 million persons infected with Schistosoma were Egyptians. $[9,10]$. Two of the three most important human species of Schistosoma are endemic in Egypt: S. haematobium, which primarily causes disease in the urinary tract, and S. mansoni, which principally causes morbidity in the gut and liver. In 1851, Theodore Bilharz, for whom the clinical disease bilharziasis was named, first described the trematode during autopsy of a patient in Cairo. Leiper, working in Egypt from 1913 to 1918, established the connection between skin exposure to canal water and infection, confirmed the life cycle with the snail as the intermediate host, and that the terminal and lateral spine eggs came from separate species. The association of chronic liver disease, characterized by hepatosplenomegaly and portal hypertension with schistosomiasis mansoni was first made by William St. Claire Symmers, also while working at Kasr El Aini Hospital in Cairo, when he described clay pipe stem fibrosis in 1904 [11]. The aim of this study was to assess the incidence and impact of HBV and HCV infection in patients with liver disease in Damietta City which represents the biggest caustic in Egypt

${ }^{*}$ Corresponding author: Hussein M. El-Shafei, Ministry of Agriculture, Port Said Egypt, E-mail: hshafei154@yahoo.com

Received June 19, 2012; Accepted August 25, 2012; Published August 30, 2012 Citation: El-Shafei HM (2012) Incidence of Chronic Hepatitis B and C Virus Infection in Damietta, Egypt. J Liver 1:111. doi:10.4172/2167-0889.1000111

Copyright: (c) 2012 El-Shafei HM. This is an open-access article distributed under the terms of the Creative Commons Attribution License, which permits unrestricted use, distribution, and reproduction in any medium, provided the original author and source are credited. 
because it is located at Nile Delta at the end of the River Nile branch the population is 950,000 person. About $40 \%$ was infected by HBV and HCV.

\section{Materials and Methods}

This was a cohort hospital-based study in Damietta during the period 2003-2005. Information was gathered from the hepatitis disease registry of the general hospital or private clinic in Damietta with symptoms and signs of hepatitis. Viral hepatitis is classified into acute Hepatitis A (BI), acute Hepatitis B (BII), other Acute Viral Hepatitis (BIII), Chronic Viral Hepatitis (BV) and unspecified Viral Hepatitis (BIV) [10]. All cases of Acute and Chronic Viral Hepatitis $\mathrm{B}$ are classified under B-II and acute and chronic viral Hepatitis C is classified under B-V. From a total of 146 patients in Damietta with hepatitis documented over the study period. Their mean age was 48 years (range22 -68 years). We studied all patients with HBV and HCV infection. Differentiation between chronic HBV and HCV infection was based on the presence of classical ground-glass hepatocytes and positive staining for hepatitis B surface antigen in cases of $\mathrm{HBV}$ infection.

\section{Evaluation}

The following biochemical assays were performed: Serum a-GST, ALT, AST, S-GGT, Alkaline Phosphotase (ALP). Venous blood sample were collected and kept $30 \mathrm{~min}$, at room temperature. The sample was centrifuged at $2500 \mathrm{r}$. p. m. for $20 \mathrm{~min}$, and serum was separated. For internal quality control the following human based control sera are available: QN.0050CH with normal or close to normal control values. Serum samples were tested for anti-HCV according to the manufacturer's instructions with a second-generation enzyme immunoassay [EIA; Abbott GmbH, Delkenheim, Germany]. Sera were also tested for hepatitis B surface antigen [HbsAg] via EIA [Abbott GmbH, Delkenheim, Germany]. Chi-square test for trends was utilized with $\mathrm{p}<0.05$ as significant. In order to compare the mean regional HCV seroprevalence, and continuous variables we used the person's correlation coefficient (r). The level of statistical significance was established at 0.05 with a statistical power of $80 \%$ [11]. Statistical analysis was performed using Spss statistical package for social sciences (Spss) according to [12]. The levels of parameters were analyzed by ANOVA; Mann-Whitney $t$-test was used for comparison between groups.

\section{Results}

Table 1 show the incidence of HBV and HCV infection per 146 patients with liver disease over each year of the study. Of the 146 patients with liver disease who were screened during the period 2003-2005, 37 (25 men, 12 women) (25.3\%) had HCV and 13 (9 men, 4 women) (8.9\%) had HBV infection. In every year, HCV was more common than $\mathrm{HBV}$. However, there was a notable increase in the incidence of HCV in patients with liver disease during recent years, reaching 18 per 146 patients in 2005. Incidence of HBV it was 6 per 146 in the same year. The rate of HCV was higher in those of men (25) than in women (12) (17.12\% for all the years combined versus $8.21 \%$ ).

Table 2 present the number of cases of Hepatitis B and Hepatitis C Virus infection reported patients with liver disease by sex during the period 2003-2005. There was a sharp increase in the number of cases of HCV in liver patients in 2005 compared with 2003 (2.2-fold higher in men and 2.3-fold higher in women). Over the years, the rate of HCV and HBV infection was higher in male than female patients $(69.2 \%$ versus $30.7 \%$ for $\mathrm{HBV}$ and $67.5 \%$ versus $32.4 \%$ for $\mathrm{HCV}$ ).
Table 3 shows the activity of AST, ALT, $\alpha$-GST, GGT and Alkaline Phosphatase in patients with hepatitis $\mathrm{C}$ virus. Of the patients who were positive for HBsAg and anti-HCV positive patients had liver dysfunction as evidenced by (ALT, AST, $\boldsymbol{\alpha}$-GST, GGT, and ALP) levels. The mean value of serum AST and ALT of patients with Hepatitis C virus was increased $185.5 \pm 14.64,278.6 \pm 13,75,359.0 \pm 10$. and to $173.16 \pm 13.94,260.60 \pm 15.43,324.55 \pm 7.15$, the mean value of serum $\boldsymbol{\alpha}$-GST of patients with acute hepatitis was highly significantly increased to $37.25 \pm 8.90,58.8 \pm 12.5,91.92 \pm 12.5985$, the mean value of serum GGT in patients with acute hepatitis was significantly increased to $61.60 \pm 5.65,76.8 \pm 5.58$, and $93.29 \pm 3.44$ and the mean value of serum ALP of patients with acute hepatitis was highly significantly increased to : $174.33 \pm 8.996,175.26 \pm 15.39$, and $236.80 \pm 12.80$ respectively.

Table 4 comparing the proportion of HBV and HCV among patients with liver disease in studies from different countries, the proportion of HCV in Egypt (74\%) were different and very higher than to the proportion in Qatar (29.4\%) Pakistan (29.0\%) and India (31.5\%). $\mathrm{HBV}$, on the other hand, is relatively rare in Egypt and incidence was relatively lower than in the USA and the Far East.

\section{Discussion}

According to the estimate of the World Health Organization (WHO) [13] over 200 million people in 74 countries in the world are affected and 500-600 million are at risk of having schistosomiasis. Schistosomiasis or bilharziasis is a helminthic infection of the mesenteric, portal and pelvic venous system. The life cycle involves the human as definitive host and an aquatic snail as intermediate host. The main pathologic effects are the progressive damage to various organs

\begin{tabular}{|c|c|c|c|}
\hline Variable & $\begin{array}{c}\text { No of HVB(13) } \\
\text { \&,HCV(37) } \\
\text { Infected }\end{array}$ & $\begin{array}{c}\text { No of Total infected } \\
\mathbf{( 5 0 )}\end{array}$ & $\begin{array}{c}\text { No of Liver disease } \\
\mathbf{( 1 4 6 )}\end{array}$ \\
\hline Hepatitis B & No \% & No \% & No \% \\
\hline 2003 & 323.07 & 36.00 & 32.05 \\
\hline 2004 & 430.70 & 48.00 & 42.73 \\
\hline 2005 & 646.15 & 612.00 & 64.10 \\
\hline Total & 13100.0 & 1326.00 & 138.90 \\
\hline Hepatitis C & & & 85.47 \\
\hline 2003 & 821.62 & 816.00 & 117.53 \\
\hline 2004 & 1129.72 & 1122.00 & 1812.32 \\
\hline 2005 & 1848.64 & 1836.00 & 3725.32 \\
\hline Total & 37100.0 & 3774.00 & 5034.24 \\
\hline Total & 50100.0 & 50100.00 & \\
\hline
\end{tabular}

Table 1: Number of cases of hepatitis $B$ and $C$ virus infection reported in patients with liver disease during the period 2003-2005.

\begin{tabular}{|c|c|c|c|}
\hline Variable & $\begin{array}{c}\text { Male } \\
\text { No } \%\end{array}$ & $\begin{array}{c}\text { Female } \\
\text { No } \%\end{array}$ & $\begin{array}{c}\text { Total } \\
\text { No }\end{array}$ \\
\hline Hepatitis B & & & \\
\hline 2003 & 215.38 & 17.69 & 3 \\
\hline 2004 & 323.07 & 17.69 & 6 \\
\hline 2005 & 430.70 & 215.38 & $\mathbf{1 3}$ \\
\hline Total & $\mathbf{9 6 9 . 2}$ & $\mathbf{4 3 0 . 7 0}$ & 8 \\
\hline Hepatitis C & & & 11 \\
\hline 2003 & 513.51 & 38.10 & 18 \\
\hline 2004 & 924.32 & 25.40 & $\mathbf{3 7}$ \\
\hline 2005 & 1129.72 & 718.91 & $\mathbf{5 0}$ \\
\hline Total & $\mathbf{2 5 6 7 . 5}$ & $\mathbf{1 2 3 2 . 4 0}$ & $\mathbf{1 6}$ \\
\hline Total & $\mathbf{3 4}$ & & \\
\hline
\end{tabular}

Table 2: Number of cases of hepatitis $B$ and $C$ virus infection reported patients with liver disease by sex during the period 2003-2005. 


\begin{tabular}{|c|c|c|c|c|c|c|c|}
\hline Year & Cases & AST $(\mathrm{U} / \mathrm{L})$ & ALT $(\mathrm{U} /)$ & a-GST $(\mathrm{U} / \mathrm{L})$ & GGT $(\mathrm{U} / \mathrm{L})$ \\
\hline 2003 & Patients (8) & $185.5 \pm 14.64 \dagger$ & $173.16 \pm 13.94 \dagger$ & $37.25 \pm 8.90^{*}$ & $61.60 \pm 5.65 \dagger$ & $174.33 \pm 8.996^{*}$ \\
\hline 2004 & Patients (11) & $278.6 \pm 13.75 \dagger$ & $260.60 \pm 15.43 \dagger$ & $58.8 \pm 12.5^{* *}$ & $76.80 \pm 5.58 \dagger$ & $175.26 \pm 15.39$ \\
\hline 2005 & Patients (18) & $359.0 \pm 10.85 \dagger$ & $324.55 \pm 7.15 \dagger$ & $91.92 \pm 12.59 \dagger$ & $93.29 \pm 3.44 \dagger$ & $236.80 \pm 12.80 \dagger$ \\
\hline
\end{tabular}

Values represent mean \pm S.E of patients

0.05 compared to control values $>^{*} \mathrm{p}$

0.01 compared to control values ${ }^{* *} \mathrm{p}$

0.001 compared to control values $>+p$

(control values recorded from Seronegativity patients)

Table 3: The activity of AST, ALT, a-GST, GGT and Alkaline Phosphatase in patients with Hepatitis C Virus during the period $2003-2005$.

\begin{tabular}{|c|c|c|c|}
\hline Country & HBV & HCV & Source \\
\hline & $\%$ & 29.4 & \\
\hline Qatar & 2.5 & - & {$[18]$} \\
\hline USA & $5-10$ & - & {$[12]$} \\
\hline Singapore & $10-40$ & $3.0-31.5$ & 29 \\
\hline Italy & - & {$[14]$} & {$[20]$} \\
\hline India & - & 74 & {$[17]$} \\
\hline Pakistan & - & {$[21]$} \\
\hline Egypt & - & {$[7]$} \\
\hline
\end{tabular}

USA = United States of America

Table 4: Virus (HBV) and C Virus (HCV) infection among patients with liver disease in different countries.

resulting from immunologic reactions to the eggs and the parasite deposited in the tissue. The hepatic fibrosis and portal hypertension occur in the intestinal form, while obstruction and superimposed infection occur in the urinary form. Hepatitis $\mathrm{C}$ virus (HCV) has been identified as the major etiologic agent of post-transfusional and sporadic non-A, non-B hepatitis and contains a positive-stranded Ribonucleic Acid (RNA) genome [14]. The WHO estimated that almost 170 million people, equivalent to $3 \%$ of the world's population, have been exposed to HCV [15]. The prevalence of HCV infection has been investigated in a number of countries and wide variations (1$5.5 \%$ ) have been reported [16]. The highest prevalence rate of $20 \%$ has been reported among Egyptian nationals $[17,18]$. Concurrent infection with HCV and Schistosoma mansoni, is the major cause of chronic liver disease and liver cirrhosis $[19,20]$. Viral hepatitis is the most common cause of chronic liver disease throughout the world [21,22]. Chronic HBV accounts for $5 \%-10 \%$ of cases of chronic liver disease and cirrhosis in the USA [21]. In our study, $43.14 \%$ of patients with liver disease had HCV or HBV. A study in Singapore showed that chronic $\mathrm{HCV}$ - and HBV-related liver disease constituted $57 \%$ of all indications for adult liver transplants [23]. A study in Romania on chronic HCV and $\mathrm{HBV}$ infections showed that an association with chronic liver disease was seen in half the patients [24]. A study in Qatar showed that chronic HCV- and HBV-related liver disease constitutes 31.9\% [25]. In Singapore the prevalence of HBV related liver diseases was high, which was not surprising as $\mathrm{HBV}$ is endemic with a $4.1 \%$ carrier rate and complication developing in $10 \%-40 \%$ of patients with chronic HBV [23]. In Qatar, HBV was relatively rare, $2.5 \%$; HCV was more common in patients with liver disease (29.4\%). In contrast, HCV is relatively rare in Singapore and in parts of Asia [26]. In addition, studies from India have shown a prevalence of HCV of 3\%-31.5\% in patients with cirrhosis and chronic liver disease $[27,28]$. However, clinical studies from southern Europe and the USA have shown a high percentage of $\mathrm{HCV}$ infection in patients with cirrhosis [23], which is consistent with our findings. There is considerable variability in the prevalence of $\mathrm{HBV}$ and HCV between different countries and ethnic groups. For instance, the prevalence of HCV in people with chronic liver disease has been estimated, at 62\%-74\% in Italy [29], 74\% in Egypt [7] and only $29 \%$ in
Pakistan [30]. It is evident from the study findings that HCV is a major cause of chronic liver disease in Egypt. Poynard, Bedossa and Opolon reported that approximately 300 million people infected worldwide with HCV will progress to cirrhosis or liver failure, and would need a transplant in the future [31].

Alanine Amino-Transferase (ALT) levels in the blood may rise to twenty above normal. Excess (ALT) leaks into the bloodstream when liver cell are injured or dying [32-34] reported that in acute hepatocelluler injury such as infection and toxic hepatitis, Alanine Amino-Transferase (ALT) and Aspartate Aminotransferase (AST) levels may increase 20 to 50 fold, even up to 100 fold of the upper limit of normal range. Our results are in accordance with [35] during acute HCV infection [36] reported that elevated aminotransferase suggest hepatocellulare damge. In severe viral hepatitis that causes extensive acute necrosis [37] reported that AST levels are highest in acute hepatocellular disorders. In viral hepatitis, levels may reach 100 times. The mean value of serum (AST) of patients with chronic hepatitis was increased to $309 \pm 13.26$ these results are in accordance with [38]. The mean value of serum Gamma glutamyl transferase (S-GGT) in patients is in accordance with many authors [36] reported that in acute infection hepatitis, S-GGT elevation is moderates (2-5 folds $24.77 \pm 11.28$. These results are in agreement with [39] who reported that $\boldsymbol{\alpha}-\mathrm{GST}$ is more frequently elevated than AST in chronic active hepatitis increase and is less useful than ALT levels. The mean value of serum Alkaline Phosphatase (ALP) in patient with acute hepatitis is in accordance with [40] in chronic hepatitis, the mean value of alkaline phosphatase in patients with chronic hepatitis was increased to $207.59 \pm 12.45$. These results are in good agreement with those of [37] who reported that slight to moderate increase in (ALP) activity occur in many patients with hepatocellular disorders, such as hepatitis and cirrhosis, chronic hepatitis and transient increases may occur in all types of liver disease. $\boldsymbol{\alpha}$-glutathione-s- transferase may be as good serologic marker of hepatocellular damage because of its low molecular weight. The mean value of serum $\boldsymbol{\alpha}$-GST of patients with acute hepatitis was in accordance with those of [41] that plasma $\boldsymbol{\alpha}$-GST increased earlier than liver transaminase levels, $\alpha$-GST may be used in monitoring hepato 
cellular damage during the progression of sepsis. In Chronic Hepatitis: the patient mean value of serum $\boldsymbol{\alpha}$-GST was increased to $24.77 \pm 11.28$. These results are in agreement with [39] who reported that $\boldsymbol{\alpha}$-GST is more frequently elevated than AST in chronic active hepatitis.

\section{Conclusion}

The present study findings revealed that over $43.14 \%$ of patients in Damietta Egypt with liver disease had viral HBV or HCV, with HCV playing the greater role, HBV and HCV infection are both preventable. In order to limit the spread of hepatitis, efforts must be directed at minimizing exposure to sources of infection. Further studies are necessary to evaluate the sociodemographic and other associated risk factors involved with HBV and HCV infection in patients with liver disease. From a molecular epidemiologist viewpoint, the prevalent $\mathrm{HBV}$ and HCV genotypes and subtypes (e.g., HBV genotypes A-H, HCV genotypes 1-6) should be reported in future studies.

\section{References}

1. Schiff ER, Sorrell MF, Maddrey NC, eds (2003): Diseases of the liver. Lippincott Williams and Wilkins 9: 741-744.

2. Purcell RH (1994) Hepatitis viruses: Changing patterns of human disease. Proc Natl Acad Sci USA 91: 2401-2406.

3. Lok S (2002) Chronic hepatitis B. N Engl J Med 346: 1682-1683.

4. NIH Consensus Development Program (2002) Management of hepatitis C (2002) National Institutes of Health Consensus Conference Statement.

5. Recommendations and reports (2003) Appendix Hepatitis A and B vaccines. Morb Mortal Wkly Rep 52: 34-36.

6. Reiss G, Keeffe EB (2004): Hepatitis vaccination in patients with chronic liver disease. Aliment Pharmacol Ther. 19: 715-727.

7. Waked IA, Saleh SM, Moustafa MS, Raouf AA, Thomas DL et al. (1995) High prevalence of hepatitis $C$ in Egyptian patients with chronic liver disease. Gut 37: 105-107.

8. Strickland GT (2006) Liver disease in Egypt: Hepatitis C superseded schistosomiasis as a result of iatrogenic and Biological factors. Hepatology 43 : 915-922.

9. Abdel-Wahab M. Schistosomiasis in Egypt. CRC Press 1982.

10. International statistical classification of diseases and related health problems: (1992) 10th revision. Geneva World Health Organization.

11. Bergmaschi DP et al. Introducao a Bioestatica Sao Paulo. Material de apoio Didatico de Curso de Atualizacao do programa de Verao da faculdade de Saude Publica da Universidade de Sao Paulo.

12. Narusis M.J (2006) Statisticsal package for social sciences (spss) 14.0 Guide to data analysis. Prentice Hall.

13. The World Health Organization (1996) Infectious Diseases Kill Over 17 Million People A Year: WHO Warns of Global Crisis. 13: 617-623.

14. Takamizawa A, Mori C, Fuke I, Manabe S, Murakami S, et al. (1991) Structure and organization of the hepatitis $C$ Virus genome isolated from human carriers. J Virol 65: 1105-1113.

15. Global surveillance and control of hepatitis C. Report of a WHO Consultation organized in collaboration with the Viral Hepatitis Prevention Board, Antwerp, Belgium. J Viral Hepat 6: 35-47.

16. Shobokshi OA, Serebour FE, Al-Drees AZ, Mitwalli AH, Qahtani A, et al. (2003) Hepatitis C virus seroprevalence rate among Saudis. Saudi Med J 24: S81-S86.

17. Frank C, Mohamed MK, Strickland GT, Lavanchy D, Arthur RR, Magder LS, et al. (2000) The role of parenteral antischistosomal therapy in the spread of hepatitis C virus in Egypt. Lancet 355: 887-891.
18. Mohamed MK, Rakhaa M, Soheir M, Saber M (1996) Viral hepatitis C infection among Egyptians The magnitude of the problem: epidemiological and laboratory approach. J Egypt Public Health Assoc 71: 79-111.

19. Halim AB, Garry RF, Dash S, Gerber MA (1999) Effect of schistosomiasis and hepatitis on liver disease. Am J Trop Med Hyg 60: 915-920.

20. Kamal SM, Madwar MA, Bianchi L, Tawil AE, Fawzi R, et al. (2000) Clinical, virological and histopathological features: Long-term follow-up in patients with chronic hepatitis C co-infected with S. mansoni. Liver 20: 281-289.

21. Types of liver diseases (2008): Liverindia.com

22. http://www.hepnet.com/hepc/aasld00/terrault.html

23. James L, Fong CW, Foong BH, Wee MK, Chow A, et al. (2001) Hepatitis B seroprevalence study 1999. Singapore Med J 42: 420-4.

24. Tănăsescu C, Pârvu M, Antohi I, Lazăr S (1999) The significance of chronic hepatitis $B$ and $C$ virus infections in some connective tissue diseases: the association with chronic liver disease. Rom J Intern Med 37: 53-64.

25. Leung NW (2002) Management of viral hepatitis C. J Gastroenterol Hepato 17: S146-S154.

26. Aggarwal N(2001) HCV as a cause of liver cirrhosis: frequency and genotype distribution. Indian journal of gastroenterology 20: A83.

27. Rikabi A, Bener A, Al-Marri A, Al-Thani S (2009) Hepatitis B and C vira infections in chronic liver disease: a population based study in Qatar. East Mediterr Health J 15: 778-784.

28. Fattovich G, Tagger A, Brollo L, Giustina G, Pontisso P, et al. (1991) Hepatitis C virus infection in chronic hepatitis B virus carriers. J Infect Dis 163: 400-402.

29. Simonetti RG, Cammà C, Fiorello F, Cottone M, Rapicetta M, et al. (1992) Hepatitis $C$ virus infection as a risk factor for hepatocellular carcinoma in patients with cirrhosis. A case-control study. Ann Intern Med 116: 97-102.

30. Tong C, Khan R, Beeching NJ, Tariq WU, Hart CA, et al. (1996) The occurrence of hepatitis $B$ and $C$ viruses in Pakistani patients with chronic liver disease and hepatocellular carcinoma. Epidemiol Infect 117: 327-332

31. Poynard T, Bedossa P, Opolon P (1997) Natural history of liver fibrosis progression in patients with chronic hepatitis C. The OBSVIRC, METAVIR, CLINIVIR, and DOSVIRC groups. Lancet 349: 825-832.

32. Daniel HD, David J, Grant PR, Garson JA, Chandy GM, et al. (2008) Whole Blood as an Alternative to Plasma for Detection of Hepatitis C Virus RNA. J Clin Microbiol 46: 3791- 3794

33. Lewandrowski K (2002) Clinical chemistry laboratory management and clinical correlation. Lippincott Williams \& Wilkins 2468-2478.

34. Sidlova K, Skalická V, Kotaska K, Pechová M, Chada M, et al. (2003) Serum alpha-glutathione S-transferase as a sensitive marker of hepatocellular damage in patients with cystic fibrosis. Physiol Res 52: 361-365.

35. Herve S, Savoye G, Riachi G, Hellot MF, Goria O, et al. (2001) Chronic hepatitis $\mathrm{C}$ with normal or abnormal aminotransferase levels: is it the same entity? Eur $\mathrm{J}$ Gastroenterol Hepatol 13: 495-500.

36. Burtis C, Bruns (2001) Tietz fundamentals of clinical chemistry.W.B. Saunders company. London, Toronto and Tokyo 10: 354-355.

37. Bishop M, Fody EP, Schoeff LE (2005) Clinical chemistry: principle, procedures correlation. Lippincott Williams \& Wilkins.

38. Marshall WJ (2000) Clinical chemistry. Mosby London 4: 82-84

39. Williams DL, Marks V (1998) Scientific foundations of biochemistry in clinica Practice. Butterworth- Heinemann.

40. Koo DJ, Zhau M, Chaudry IH, Wang P (2000) Plasma alpha-glutathione S-transferase: a sensitive indicator of hepatocellular damage during polymicrobial sepsis. Arch Surg 135: 198-203.

41. Pratt DS, Kaplan MM (2003) Laboratory tests. In Schiff E R, sorrell MF Maddrey WC, eds. Schiffs disease of the liver 9: 205-202. 